Boise State University

ScholarWorks

$12-1-2010$

Labile Soil Carbon Inputs Mediate the Soil Microbial Community Composition and Plant Residue Decomposition Rates

Marie-Anne de Graaff

Boise State University

Aimee T. Classen

The University of Tennessee

Hector F. Castro

Oak Ridge National Laboratory

Christopher W. Schadt

Oak Ridge National Laboratory 


\title{
Labile soil carbon inputs mediate the soil microbial community composition and plant residue decomposition rates
}

\author{
Marie-Anne de Graaff ${ }^{1,2}$, Aimee T. Classen ${ }^{3}$, Hector F. Castro ${ }^{2,3}$ and Christopher W. Schadt ${ }^{2}$ \\ ${ }^{1}$ Department of Biological Sciences, Boise State University, Boise, ID 83725, USA; ${ }^{2}$ Molecular Microbial Ecology Group, Biosciences Division, Oak Ridge \\ National Laboratory, Oak Ridge, TN 37831, USA; ${ }^{3}$ Department of Ecology and Evolutionary Biology, The University of Tennessee, Knoxville, TN 37966, USA
}

Author for correspondence:

Marie-Anne de Graaff

Tel: +1 2084263262

Email: marie-annedegraaff@boisestate.edu

Received: 25 May 2010

Accepted: 6 July 2010

New Phytologist (2010) 188: 1055-1064 doi: 10.1111/j.1469-8137.2010.03427.x

Key words: bacteria, carbon-13, decomposition, exudation, fungi, priming, $\mathrm{PPCR}$, root exudation.

\section{Summary}

- Root carbon (C) inputs may regulate decomposition rates in soil, and in this study we ask: how do labile $\mathrm{C}$ inputs regulate decomposition of plant residues, and soil microbial communities?

- In a 14 d laboratory incubation, we added $C$ compounds often found in root exudates in seven different concentrations $(0,0.7,1.4,3.6,7.2,14.4$ and $21.7 \mathrm{mg} \mathrm{C} \mathrm{g}{ }^{-1}$ soil) to soils amended with and without ${ }^{13} \mathrm{C}$-labeled plant residue. We measured $\mathrm{CO}_{2}$ respiration and shifts in relative fungal and bacterial rRNA gene copy numbers using quantitative polymerase chain reaction (qPCR).

- Increased labile $C$ input enhanced total $C$ respiration, but only addition of $C$ at low concentrations $\left(0.7 \mathrm{mg} \mathrm{C} \mathrm{g}^{-1}\right)$ stimulated plant residue decomposition $(+2 \%)$. Intermediate concentrations $\left(1.4,3.6 \mathrm{mg} \mathrm{C} \mathrm{g}^{-1}\right)$ had no impact on plant residue decomposition, while greater concentrations of $C\left(>7.2 \mathrm{mg} \mathrm{g} \mathrm{g}^{-1}\right)$ reduced decomposition $(-50 \%)$. Concurrently, high exudate concentrations (> $3.6 \mathrm{mg} \mathrm{C} \mathrm{g}^{-1}$ ) increased fungal and bacterial gene copy numbers, whereas low exudate concentrations $\left(<3.6 \mathrm{mg} \mathrm{C} \mathrm{g}^{-1}\right)$ increased metabolic activity rather than gene copy numbers.

- These results underscore that labile soil $C$ inputs can regulate decomposition of more recalcitrant soil $\mathrm{C}$ by controlling the activity and relative abundance of fungi and bacteria.

\section{Introduction}

The soil is an important terrestrial carbon (C) sink, storing c. 4.5 times the amount of $\mathrm{C}$ contained in vegetation ( $\mathrm{Lal}$, 2004). Soil $C$ accrual is controlled by the balance between $\mathrm{C}$ input via plants and $\mathrm{C}$ output via microbial and root respiration (Jastrow et al., 2007). Root inputs contribute significantly to soil $\mathrm{C}$ pools because plants partition up to $40 \%$ of assimilated C below ground (Merckx et al., 1986). Roots also regulate soil $\mathrm{C}$ output by stimulating microbial activity through the release of root exudates (Cheng \& Kuzyakov, 2005). Root exudates are low-molecular-weight compounds that are passively released by living roots (Lynch \& Whipps, 1990; Darrah, 1996). They consist of a complex mixture of organic acids, phytosiderophores, sugars, vitamins, amino acids, purines, nucleosides, iorganic ions, gaseous molecules, enzymes and root border cells (Dakora \& Phillips, 2002; Dennis et al., 2010). Carbonrich substrates, such as sugars (50-70\% of total exudate), carboxylic acids (20-30\% of total exudate) and amino acids (10-20\% of total exudate) make up the majority of exudate compounds (Kraffczyk et al., 1984; Jones, 1998; Hutsch et al., 2002), and they are an important C source for Climited soil microbial communities (Bowen \& Rovira, 1991; Darrah, 1996). Nonetheless they are an often overlooked regulator of decomposition processes (Darrah, 1996; Kuzyakov, 2002; Phillips, 2007).

Both the quality and quantity of root exudate inputs to soil, and their importance in the $\mathrm{C}$ cycle remain controversial (Kuzyakov et al., 2000) and we have a poor understanding of how root exudate inputs impact more recalcitrant $\mathrm{C}$ turnover. For example, in the presence of living roots, soil organic 
matter (SOM) C and $\mathrm{N}$ mineralization can decrease by up to $30 \%$, or increase by as much as $100 \%$, relative to nonrhizosphere soil (Dormaar, 1990; Cheng \& Kuzyakov, 2005). An increase in plant- or soil-derived $\mathrm{C}$ respiration in response to labile $\mathrm{C}$ additions is termed a 'real positive priming effect' (Kuzyakov et al., 2000), but if an increase in respired $\mathrm{CO}_{2}$ is derived from root exudate $\mathrm{C}$ only, and is not accompanied by increases in the decomposition rate of recalcitrant substrates, the process is referred to as 'an apparent priming effect' (Kuzyakov, 2002). Previous research showed that the supply of easily assimilable compounds to soil may result either in large (Hamer \& Marschner, 2002, 2005b) or small (Dalenberg \& Jager, 1989; Kuzyakov et al., 2007) real positive priming effects, or in no (Wu et al., 1993) or negative (Kuzyakov \& Bol, 2006; Blagodatskaya et al., 2007) changes in plant residue decomposition. Understanding the causes of this variation will enable a better understanding of root impacts on the soil $\mathrm{C}$ cycle.

Soil microbial communities play a large role in decomposition processes, and root exudate inputs have an impact on their community structure and C-use efficiency (De Deyn et al., 2008). At a coarse scale, microbial communities can be broken down into fungal and bacterial groups, and research indicates that these groups function differently in the decomposition process. In general, bacterial decomposition pathways support high turnover rates of easily available substrates, while slower fungal-dominated decomposition pathways more complex organic materials (Wardle et al., 2002). Fontaine \& Barot (2005) propose that observed priming effects of soil $\mathrm{C}$ decomposition result from the succession of opportunist microorganisms (such as bacteria) that specialize in the decomposition of easily available resources to slow-growing, efficient microorganisms (such as fungi) that feed on polymerized SOM. However, this hypothesis is the subject of some debate; a rapid increase in soil organic carbon (SOC) mineralization (e.g. priming) after substrate additions might be the result of an increase in microbial opportunist activity, rather than a shift to slow-growing microorganisms (De Nobili et al., 2001; Hamer \& Marschner, 2002; 2005a,b; Hamer et al., 2004).

To shed light on the impact of root exudation on SOM decomposition, we examined how labile $\mathrm{C}$ compounds, commonly found in root exudates, alter plant residue decomposition and the relative abundances of fungi and bacteria responsible for those changes. We focus on $\mathrm{C}$ because it makes up over $90 \%$ of root exudates and often limits the growth of microbial communities. We predict that soil bacterial and fungal communities will preferentially use labile $\mathrm{C}$ compounds and that shifts in the relative proportion of bacterial and fungal communities will determine both the size and direction of the real priming effect.

Using experimental soil incubations, we added a synthetic root exudate cocktail at seven concentrations $(0,0.7$, 1.4, 3.6, 7.2, 14.4 and $21.7 \mathrm{mg} \mathrm{C} \mathrm{g}^{-1}$ ) of C-input to soils with and without ${ }^{13} \mathrm{C}$-labeled plant residue and measured the respiration rates over $14 \mathrm{~d}$. These treatments enabled us to differentiate between the $\mathrm{C}$ respired from added plant residue and that from pre-existing soil C. The artificial 'exudate cocktail' contained the most ubiquitous $\mathrm{C}$ compounds of root exudates and combined them in realistic ratios (Kraffczyk et al., 1984; Jones, 1998; Hutsch et al., 2002). Estimates of the quantity of $\mathrm{C}$ released in soil via root exudates vary depending on the method of collection, ranging from 50 to $1500 \mu \mathrm{g} \mathrm{g}^{-1}$ soil d ${ }^{-1}$ (Trofymow et al., 1987; Jones \& Darrah, 1993; Meharg \& Kilham, 1995; Cheng, 1996). The exudate cocktail in our study was applied as a single pulse of $\mathrm{C}$ substrate that covered the full spectrum of root-derived labile soil $\mathrm{C}$ concentrations measured in the soil and beyond, to assess the effect of different thresholds of added exudate on priming. To monitor decomposition, we measured ${ }^{13} \mathrm{C}-\mathrm{CO}_{2}$ efflux over $14 \mathrm{~d}$, and we determined shifts in the relative abundance of fungi and bacteria at days 3 and 14 using real-time PCR. Together these data will enable us to better understand how changes in root-derived labile $\mathrm{C}$ inputs may impact overall SOM decomposition.

\section{Materials and Methods}

\section{Production of labeled material}

Panicum virgatum $\mathrm{L}$. Alamo (hereafter referred to as switchgrass) seeds were surface-sterilized using $70 \%$ ethanol and $30 \%$ commercial bleach, vernalized at $6^{\circ} \mathrm{C}$ for $3 \mathrm{~d}$, germinated on agar for $2 \mathrm{~d}$, and then established in a sealed mesocosm filled with coarse silica sand (maintained at 60\% water-holding capacity, WHC). The mesocosm consisted of a stainless steel soil bin $(50 \times 50 \times 30 \mathrm{~cm})$ and a transparent Plexiglas cuvette $(50 \times 50 \times 45 \mathrm{~cm})$ inserted into a climate-controlled growth chamber (Conviron ${ }^{\circledR}$ CMP3224, Pembina, ND, USA). The photosynthetically active (400$700 \mathrm{~nm}$ ) photon fluence rate of $400 \mu \mathrm{mol} \mathrm{m}^{-2} \mathrm{~s}^{-1}$, a $16: 8 \mathrm{~h}$ day : night cycle, and a $20: 15^{\circ} \mathrm{C}$ day : night temperature corresponded to a $25: 18^{\circ} \mathrm{C}$ day : night temperature within the mesocosm and was maintained for the duration of the experiment.

Plants were continuously labeled with 99 atom $\%{ }^{13} \mathrm{C}$ enriched $\mathrm{CO}_{2}$ gas (Cambridge Isotope Laboratories, Andover, MA, USA). Regulated with an IRGA (model 820-LC; Li-Cor, Lincoln, NE, USA), the $\mathrm{CO}_{2}$ concentration in the mesocosm was maintained at c. $500 \mu \mathrm{mol}$ $\mathrm{mol}^{-1}$. To decrease fungal growth that was inhibiting plant germination and growth, the mesocosm was opened periodically and treated with a diluted $(1: 100)$ algaecide : fungicide solution (Zero Tol; BioSafe Systems LLC., East Hartford, CT, USA). The fungicide was applied at a 10 -fold lower concentration than the standard agricultural application of this fungicide. 
After 2 months of growth, the labeled above- and belowground plant biomass was harvested, dried at $70^{\circ} \mathrm{C}$ for $c$. $48 \mathrm{~h}$, and ground to $2.5 \mathrm{~mm}$ using a Wiley mill. Subsamples were further ground using a ball mill and analyzed for total $\mathrm{C}$ concentrations, total $\mathrm{N}$ concentrations, and stable $\mathrm{C}$ isotope ratios $\left({ }^{13} \mathrm{C} /{ }^{12} \mathrm{C}\right)$ using an Integra-CN, continuous flow, isotope ratio mass spectrometer (serCon Ltd, Crewe, UK) coupled with a LECO CN-2000 elemental analyzer (LECO Corporation, St Joseph, MI, USA).

\section{Root exudates}

We made six concentrations of synthetic root exudates that mimicked observed root exudate $\mathrm{C}$ release by mixing the most common $\mathrm{C}$ compounds found in root exudates. The relative concentrations of sugars, organic acids, and amino acids were kept constant and reflect ratios observed in the field (c. 60\% sugars, c. 35\% organic acids and c. 2\% amino acids) (Kraffczyk et al., 1984; Jones, 1998; Hutsch et al., 2002). The stock solution contained: D-glucose (28 $\left.\mathrm{mg} \mathrm{ml}^{-1}\right)$, D-fructose $\left(9.4 \mathrm{mg} \mathrm{ml}^{-1}\right)$, D-xylose $\left(8 \mathrm{mg} \mathrm{ml}^{-1}\right.$ ), oxalate $\left(7.8 \mathrm{mg} \mathrm{ml}^{-1}\right)$, fumarate $\left(14.6 \mathrm{mg} \mathrm{ml}^{-1}\right)$, succinate $\left(1.2 \mathrm{mg} \mathrm{ml}^{-1}\right)$, acetate $\left(4.0 \mathrm{mg} \mathrm{ml}^{-1}\right)$, L-proline $(0.1 \mathrm{mg}$ $\left.\mathrm{ml}^{-1}\right)$, L-arginine $\left(0.1 \mathrm{mg} \mathrm{ml}^{-1}\right)$, L-glycine $\left(0.1 \mathrm{mg} \mathrm{ml}^{-1}\right)$, L-serine $\left(0.1 \mathrm{mg} \mathrm{ml}^{-1}\right)$, and glutamate $\left(0.3 \mathrm{mg} \mathrm{ml}^{-1}\right)$ (Kraffczyk et al., 1984).

\section{Incubation design}

Soil was collected $(0-10 \mathrm{~cm})$ using a hammer core from a cultivated switchgrass field (24 $\mathrm{yr}$ of cultivation) and homogenized. Soils were sieved $(2 \mathrm{~mm})$, visible roots (>2 mm) were removed, and soil was kept at $6^{\circ} \mathrm{C}$ until used. A subsample of soil was dried, ground to a fine powder, and analyzed for total $\mathrm{C}, \mathrm{N}$ and stable $\mathrm{C}$ isotope ratios $\left({ }^{13} \mathrm{C} /{ }^{12} \mathrm{C}\right)$.

After the soil was removed from the refrigerator, the soil $(10 \mathrm{~g} \mathrm{DW})$ was incubated $\left(20^{\circ} \mathrm{C}\right)$ in one of two ways: with artificial root exudates, or with artificial exudates and plant residues. The samples containing just soil and exudates, but no plant residue, were included to account for $\mathrm{CO}_{2}$ evolution from the pre-existing soil $\mathrm{C}$. These data were used to calculate plant residue-derived $\mathrm{C}$ respiration. The amount of plant residue added to each soil was kept constant $(0.1 \mathrm{~g})$, but the exudates were applied to the soil in a single pulse in one of seven $\mathrm{C}$ concentrations: $0,0.7,1.4,3.6,7.2$, 14.4, and $21.7 \mathrm{mg} \mathrm{C} \mathrm{g}^{-1}$ dry soil (Table 1 ).

Plant material was mixed with soil in $120 \mathrm{ml}$ specimen cups. The WHC of the soils was determined by calculating the difference in soil weight at the water saturation point and the oven-dry weight $\left(100^{\circ} \mathrm{C}\right)$. The exudate solutions were added homogeneously to obtain 60\% of WHC. Specimen cups were placed in 11 mason jars and $5 \mathrm{ml}$ of water was added to the bottom of the jar to maintain humidity.

\section{Microbial respiration}

A septum in the lid of each mason jar allowed air samples $(10 \mathrm{ml})$ to be removed from the headspace with a syringe. Soil $\mathrm{CO}_{2}$ evolution was measured at days $1,2,3,5,7$, and 14. Blank jars (three) that contained no soil were included to determine the background concentrations of $\mathrm{CO}_{2}$ and its ${ }^{13} \mathrm{C}$-isotopic composition. Carbon dioxide samples were collected in $12 \mathrm{ml}$ exetainers (Labco Ltd, High Wycombe, UK). Following gas sampling, the mason jars were opened, the soils were removed, and the jars were flushed with air for $30 \mathrm{~min}$. Samples were analyzed for $\mathrm{CO}_{2}$ and its $\mathrm{PDB}-{ }^{13} \mathrm{C}$ signature with a continuous flow, isotope mass spectrometer (PDZ Europa TGII trace gas analyzer and Geo 20-20 isotope ratio mass spectrometer; Sercon, Crewe, UK). For the $\mathrm{CO}_{2}$ analyses, the highest available 'certified' ${ }^{13} \mathrm{C}$ standard IAEA 309B $(+535.3$ per mille Vienna PDB standard (VPDB)) was used. Then, calibration mixtures for samples enriched beyond this were made. Nominal 99 atom\% enriched ${ }^{13} \mathrm{C}$ carbonate was mixed with natural abundance carbonate to produce $\mathrm{CO}_{2}$ at a range of enrichments from 14 to 48 atom $\%{ }^{13} \mathrm{C}$. Carbon mineralization data are expressed on the basis of oven-dry soil.

Results of the C-isotope analyses are expressed in atom\% ${ }^{13} \mathrm{C}$. To calculate the amount of $\mathrm{CO}_{2}-\mathrm{C}$ derived from ${ }^{13} \mathrm{C}$ labeled plant residues, incubated in soil with exudates, the following mass balance was used (Denef et al., 2002; de Graaff et al., 2004):

Table 1 Overview of treatments used in the incubation experiment. The soil was incubated $\left(20^{\circ} \mathrm{C}\right)$ in four different combinations: soil plus exudates; soil plus exudates and plant residue; soil plus water; and soil plus water and plant residue

\begin{tabular}{lcl}
\hline Treatment & $\begin{array}{l}\text { Exudate addition } \\
\left(\mathrm{mg} \mathrm{C} \mathrm{g}^{-1} \text { dry soil) }\right.\end{array}$ & $\begin{array}{l}\text { Plant litter addition } \\
\left(\mathrm{g} \mathrm{g}^{-1} \mathrm{dry} \text { soil) }\right.\end{array}$ \\
\hline Soil + exudates & 0.7 & 0.0 \\
& 1.4 & 0.0 \\
& 3.6 & 0.0 \\
& 7.2 & 0.0 \\
& 14.4 & 0.0 \\
Soil + exudates + & 21.7 & 0.0 \\
plant litter & 0.7 & 0.01 \\
& 1.4 & 0.01 \\
& 3.6 & 0.01 \\
& 7.2 & 0.01 \\
Soil + water & 14.4 & 0.01 \\
Soil + water + & 21.7 & 0.01 \\
plant litter & 0.0 & 0.00 \\
\hline
\end{tabular}




$$
\begin{aligned}
\mathrm{Q}_{\mathrm{t}}{ }^{*} \text { atom } \%{ }^{13} \mathrm{C}_{\mathrm{t}}= & \mathrm{Q}_{\mathrm{p}}{ }^{*} \text { atom } \%{ }^{13} \mathrm{C}_{\mathrm{p}}+\mathrm{Q}_{\mathrm{s}+\mathrm{e}}{ }^{*} \text { atom } \%{ }^{13} \mathrm{C}_{\mathrm{s}+\mathrm{e}} \\
& +\mathrm{Q}_{\mathrm{b}}{ }^{*} \text { atom } \%{ }^{13} \mathrm{C}_{\mathrm{b}}
\end{aligned}
$$

where $Q_{t}$ is the total amount of $\mathrm{CO}_{2}-\mathrm{C}$, atom $\%{ }^{13} \mathrm{C}_{\mathrm{t}}$ is its isotopic composition; $Q_{\mathrm{p}}$ is the amount of $\mathrm{CO}_{2}-\mathrm{C}$ derived $\mathrm{C}$ from plant residue, atom $\%{ }^{13} \mathrm{C}_{\mathrm{p}}$ is the isotopic composition of plant residue (70 atom $\left.\%{ }^{13} \mathrm{C}\right) ; Q_{s+e}$ is the amount of $\mathrm{CO}_{2}-\mathrm{C}$ derived from the unlabeled soil + exudate, atom $\%{ }^{13} \mathrm{C}_{\mathrm{s}+\mathrm{e}}$ is the isotopic composition of the unlabeled soil + exudate $\left(1.1\right.$ atom $\%{ }^{13} \mathrm{C}$, on average), $Q_{b}$ is the $\mathrm{CO}_{2}-\mathrm{C}$ amount in the control blank jar and atom $\%{ }^{13} \mathrm{C}_{\mathrm{b}}$ is the isotopic composition of $\mathrm{CO}_{2}$ in the control blank jar (1.1 atom $\%{ }^{13} \mathrm{C}$ on average). The $\mathrm{CO}_{2}-\mathrm{C}$ derived from the plant residue $\left(Q_{\mathrm{p}}\right)$ during the incubation was quantified by subtracting soil respiration $\left(Q_{s+\mathrm{e}}+Q_{\mathrm{b}}\right)$ from the respiration of soil with incorporated plant materials $\left(Q_{t}\right)$.

\section{Quantification of bacterial and fungal gene copy numbers}

After mixing the soil in each container, a subsample of $5 \mathrm{~g}$ was collected and frozen $\left(-80^{\circ} \mathrm{C}\right)$ for DNA extraction and to assess the relative abundance of fungi and bacteria. Microbial DNA was extracted from $0.25 \mathrm{~g}$ soil using the PowerSoil ${ }^{\circledR}$-htp 96 Well Soil DNA Isolation Kit (MOBIO Laboratories, Inc., Carlsbad, CA, USA) in concert with a 96-well plate shaker, using a plate adapter set (MOBIO Laboratories). After extraction, the DNA concentration and its purity were determined with a nano-drop using the ND1000 Spectrophotometer (NanoDrop Technologies, Inc., Wilmington, DE, USA).

Quantitative PCR runs were set up in clear Low-Profile 96-Well PCR Plates (Bio-Rad) using $10 \mu \mathrm{l}$ iQ SYBR Green Supermix (Bio-Rad), $5 \mu \mathrm{H} \mathrm{H}_{2} \mathrm{O}, 2 \mu \mathrm{l}$ of forward primer, $2 \mu \mathrm{l}$ of reverse primer $(10 \mathrm{pM})$ and $1 \mu \mathrm{l}$ of sample. Primers used for $16 \mathrm{~S}$ rRNA bacterial genes were EUB338 (5'-ACTCCTACGGGAGGCAGCAG-3'; Lane, 1991) and Eub518 (5'-ATTACCGCGGCTGCTGG-3'; Muyzer et al., 1993); and for fungal rRNA genes were nu-SSU-1196F (5'GGAAACTCACCAGGTCCAGA-3') and nu-SSU-1536R (5'-ATTGCAATGCYCTATCCCCA-3') (Borneman \& Hartin, 2000). Samples were analyzed in duplicate with triplicate standard curves. We tested 1:10 DNA dilutions in selected samples, did not observe inhibition, and obtained similar results.

Standard curves were prepared using known amounts of DNA extracted from pure cultures carried out concomitantly with experimental samples and exhibited a linear relationship between the log of the rRNA-gene copy number and the calculated threshold $\left(\mathrm{C}_{\mathrm{t}}\right)$ value $\left(R^{2}>0.99\right)$. Escherichia coli was used for bacterial amplifications ( $c$. $180 \mathrm{bp}$ amplicon) and Saccharomyces cerevisiae for fungal amplifications (c. $340 \mathrm{bp}$ amplicon). These organisms were used to calculate the number of equivalent copies in the sample according to a standard curve. Amplification efficiencies ranged from 1.6 to 1.8 , which are consistent with other reported values (Fierer et al., 2005; Castro et al., 2010).

\section{Statistical analyses}

Statistical tests were performed on $\mathrm{CO}_{2}$ respiration rates and fungal and bacterial gene copy numbers at each sampling date during the incubation. Statistics were performed using the Univariate GLM in SPSS STATISTICS 17.0. We conducted a one-way ANOVA for each sampling date, with treatments (i.e. labile $\mathrm{C}$ input treatments, and plant residue amendments) as fixed effects. We tested for homogeneity of variance using Levene's test $(P \leq 0.01)$. If equal variance was assumed, we compared means using the least significant differences post hoc test. If equal variance was not assumed, we used the Tamhane's T2 post hoc test to compare means. The levels of significance were $P \leq 0.05$ and $P \leq 0.01$.

\section{Results}

\section{Total C respiration}

The addition of water and exudates to soil resulted in an immediate increase in $\mathrm{CO}_{2}$ respiration. Total cumulative $\mathrm{C}$ respiration (i.e. $\mathrm{C}$ derived from soil + exudates + plant residue) increased with each increase in root exudate $(P<0.001)$, although cumulative total $\mathrm{C}$ respiration was similar when concentrations of $0.7-1.4 \mathrm{mg} \mathrm{C} \mathrm{g}^{-1}$ were added to soils (Table 2). Increasing exudate additions also enhanced the maximum respiration rate (i.e. the greatest measured $\mathrm{CO}_{2}$ efflux in a $24 \mathrm{~h}$ period during the $14 \mathrm{~d}$ incubation) for almost all of the treatments $(P \leq 0.001)$. However, exudate additions of 0.7 and $1.4 \mathrm{mg} \mathrm{C} \mathrm{g}^{-1}$ resulted in similar maximum respiration rates, and exudate additions of 14.4 and $21.7 \mathrm{mg} \mathrm{C} \mathrm{g}^{-1}$ reached equal maximum respiration rates (Fig. 1a).

With increasing exudate concentrations, the time it took to reach maximum $\mathrm{C}$ respiration rates was delayed (Fig. 1a). Soils receiving the lowest amount of exudates reached maximum respiration rates on day $1(P \leq 0.001)$, whereas increasing exudate additions delayed the time it took to reach the maximum $\mathrm{CO}_{2}$ efflux rate from day 2 to day 4 (Fig. 1a).

\section{Plant- and soil-derived $\mathrm{C}$ respiration}

The difference in isotopic signature between soils containing exudates and plant residues and those containing exudates only allowed us to calculate plant residue-derived $\mathrm{C}$ respiration. Addition of the lowest amount of exudates $\left(0.7 \mathrm{mg} \mathrm{C} \mathrm{g}^{-1}\right)$ to soil resulted in an increase in total 
New

Phytologist

Table 2 Cumulative soil $\mathrm{CO}_{2}$ respiration at $14 \mathrm{~d}$

\begin{tabular}{|c|c|c|c|c|}
\hline \multirow[b]{2}{*}{ Exudate addition } & \multicolumn{2}{|c|}{ Experimentally determined $\mathrm{CO}_{2}$ respiration } & \multicolumn{2}{|c|}{ Calculated $\mathrm{CO}_{2}$ respiration } \\
\hline & $\begin{array}{l}\text { Soil + exudates } \\
\text { (mg C g }{ }^{-1} \text { soil) }\end{array}$ & $\begin{array}{l}\text { Soil + exudate + plant } \\
\text { residue }\left(\mathrm{mg} \mathrm{C} \mathrm{g}^{-1} \text { soil }\right)\end{array}$ & $\begin{array}{l}\text { Plant residue } \\
\text { ( } \mathrm{mg} \mathrm{C} \mathrm{g} \mathrm{goil)}^{-1} \text { sois }\end{array}$ & $\begin{array}{l}\text { Soil } \\
\text { (mg C g }{ }^{-1} \text { soil) }\end{array}$ \\
\hline Water only (control) & $0.09 \pm 0.004 a$ & $1.69 \pm 0.04 a$ & $1.11 \pm 0.03 a$ & $0.096 \pm 0.04$ \\
\hline $0.7 \mu \mathrm{g} C \mathrm{~g}^{-1}$ & $0.86 \pm 0.01 \mathrm{a}$ & $2.29 \pm 0.02 a$ & $1.21 \pm 0.02 b$ & $0.145 \pm 0.01$ \\
\hline $1.4 \mu \mathrm{g} \mathrm{C} \mathrm{g}^{-1}$ & $1.54 \pm 0.003 b$ & $2.31 \pm 0.12 a$ & $0.93 \pm 0.05 a$ & $0.02 \mathrm{a}$ \\
\hline $3.6 \mu \mathrm{g} \mathrm{C} \mathrm{g} \mathrm{g}^{-1}$ & $2.09 \pm 0.09 a, b$ & $3.86 \pm 0.30 b$ & $1.02 \pm 0.02 \mathrm{a}$ & 0.00 \\
\hline $7.2 \mu \mathrm{g} \mathrm{C} \mathrm{g}$ & $4.26 \pm 0.03 b, c$ & $5.17 \pm 0.06 c$ & $0.73 \pm 0.004 b$ & 0.00 \\
\hline $14.4 \mathrm{mg} \mathrm{C}^{-1}$ & $6.40 \pm 0.27 c$ & $8.62 \pm 0.07 d$ & $0.56 \pm 0.01 c$ & 0.00 \\
\hline $21.7 \mathrm{mg} \mathrm{C} \mathrm{g}^{-1}$ & $6.26 \pm 0.74 c$ & $11.5 \pm 0.07 e$ & $0.50 \pm 0.004 d$ & 0.00 \\
\hline
\end{tabular}

The second column represents the amount of $\mathrm{CO}_{2}$ respired from soils receiving exudates only. The third column represents the amount of $\mathrm{CO}_{2}$ respired from soils receiving both exudates and plant residues. The fourth column represents the contribution of plant residue to the total soil $\mathrm{CO}_{2}$ respiration. The fifth column represents the contribution of the native soil carbon to the total soil $\mathrm{CO}_{2}$ respiration.

Different letters indicate differences among treatments within a column $(P \leq 0.05)$ within each table column. Values are mean \pm SE $(n=3)$.

(a)

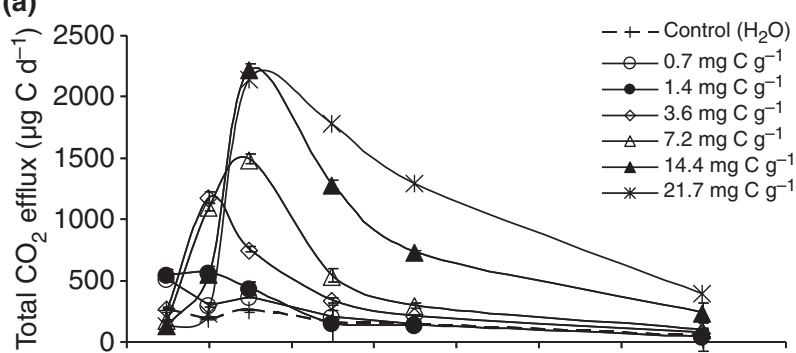

(b)

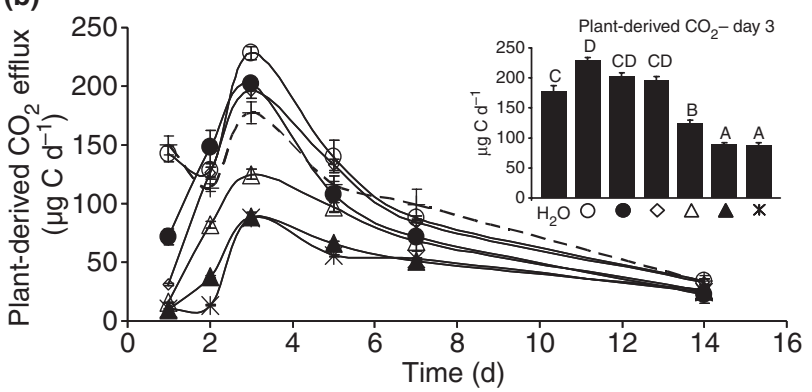

Fig. 1 Soil carbon (C) respiration rates across a range of labile $C$ additions. (a) Carbon derived from the decomposition of native soil $C$, plus added labile $C$, plus added plant residue. (b) Carbon derived from the decomposition of added plant residue; the bar graph insert highlights plant residue decomposition differences among treatments on day 3 of the incubation. Different letters indicate significant differences $(P \leq 0.05)$ among $C$-addition treatments. Values are means $\pm \mathrm{SE}(n=3)$.

cumulative plant-derived $\mathrm{C}$ respiration relative to water plus residue control treatments $(P \leq 0.05$; Table 2$)$. By contrast, addition of exudates in excess of $7.2 \mathrm{mg} \mathrm{C} \mathrm{g}^{-1}$ significantly reduced cumulative plant-derived $\mathrm{C}$ respiration relative to water-only treatments $(P \leq 0.001$; Table 2$)$.

The impact of exudate additions on plant residue turnover rates was largest on day 3 of the incubation (Fig. 1b). Addition of the lowest amount of exudates $\left(0.7 \mathrm{mg} \mathrm{C} \mathrm{g}^{-1}\right)$ significantly stimulated decomposition of plant residue by
$29 \%$ relative to the water-only treatment $(P=0.03$; Fig. 1b). Addition of 1.4 and $3.6 \mathrm{mg} \mathrm{C} \mathrm{g}^{-1}$ resulted in a trend towards increased decomposition of plant-derived $\mathrm{C}$ relative to plant-derived $\mathrm{C}$ respiration from soils receiving water only $(+14$ and $+11 \%$, respectively; Fig. $1 b)$. Additions of $7.2,14.4$ and $21.7 \mathrm{mg} \mathrm{C} \mathrm{g}^{-1}$ all resulted in significantly reduced plant residue-derived $\mathrm{CO}_{2}$ respiration relative to the soils amended with plant residue and water only, by $30 \%(P=0.003), 50 \%(P \leq 0.001)$ and $50 \%$ $(P \leq 0.001)$, respectively (Fig. $1 \mathrm{~b})$.

Soil-derived $\mathrm{CO}_{2}$ respiration was determined by subtracting the total cumulative amount of respiration in soils receiving exudates only from the amount of $\mathrm{C}$ added to the soils (Table 2). Addition of 0.7 and $1.4 \mathrm{mg} \mathrm{C} \mathrm{g}^{-1}$ resulted in a trend toward increased cumulative soil $\mathrm{C}$ efflux relative to soils receiving water only $(+20$ and $+16 \%$, respectively; Table 2).

\section{Quantification of bacterial and fungal gene copy numbers}

Methods using qPCR-generated gene copy numbers have several limitations when used to calculate absolute abundances of microorganisms (e.g. microbial biomass or cell numbers) and are far from unambiguous (Fierer et al., 2005; Rousk et al., 2010; Strickland \& Rousk, 2010). Interpreted from relative copy number alone, our data show a very consistent response and our study is highly controlled by design (e.g. using the same soil source, DNA extraction, PCR conditions, and DNA standards) especially when compared with other studies where qPCR is used across diverse soil types and ecosystems. We keep the limitations of the qPCR method in mind, and interpret any treatmentinduced shifts in gene copy number as a relative change within a group (i.e. fungi or bacteria).

Across all treatments, exudate additions increased relative bacterial and fungal gene copy numbers. Relative increases 
in bacterial and fungal gene copy numbers resulting from $\mathrm{C}$ addition were generally greater in soils amended with both exudates and plant residue than in soils amended with exudates only (Table 3 ). The relative increase in fungal gene copy numbers in response to labile $\mathrm{C}$ additions was generally higher than the relative increase in bacterial gene copy numbers, specifically in soils amended with plant residues (Fig. 2). After $3 \mathrm{~d}$ of incubation and relative to water-only treatments, fungal : bacterial gene copy ratios significantly increased following a labile $\mathrm{C}$ input of $3.6 \mathrm{mg} \mathrm{C} \mathrm{g}^{-1}$ (Fig. 2a). On day 14 of the incubation, and relative to water-only treatments, fungal : bacterial gene copy ratios significantly increased following a labile $\mathrm{C}$ input of $0.7 \mathrm{mg} \mathrm{C} \mathrm{g}^{-1}$ (Fig. 2b).

After $3 \mathrm{~d}$ of incubation and relative to treatments that received water only, fungal gene copy numbers were significantly elevated at an input of $3.6 \mathrm{mg} \mathrm{C} \mathrm{g}^{-1}$ in soils receiving both exudates and plant residues $(P \leq 0.05$; Table 3$)$. After $14 \mathrm{~d}$ of incubation and relative to water-only treatments, fungal gene copy numbers were significantly elevated at exudate additions of $0.7 \mathrm{mg} \mathrm{C} \mathrm{g}^{-1}$ in soils receiving exudates only and in soils receiving exudates and plant residues $(P \leq 0.05$; Table 3$)$. After 3 and $14 \mathrm{~d}$ of incubation and relative to water-only treatments, bacterial gene copy numbers increased at exudate additions of $14.4 \mathrm{mg} \mathrm{C} \mathrm{g}^{-1}$ when no plant residue was added to the soils $(P \leq 0.05$; Table 3). After $3 \mathrm{~d}$ of incubation and relative to water-only treatments, bacterial gene copy numbers were enhanced when exudate additions exceeded $1.4 \mathrm{mg} \mathrm{C} \mathrm{g}^{-1}$ in soils amended with plant residue and consistently increased thereafter $(P \leq 0.05$; Table 3$)$. After $14 \mathrm{~d}$ of incubation and relative to water-only treatments, bacterial gene copy

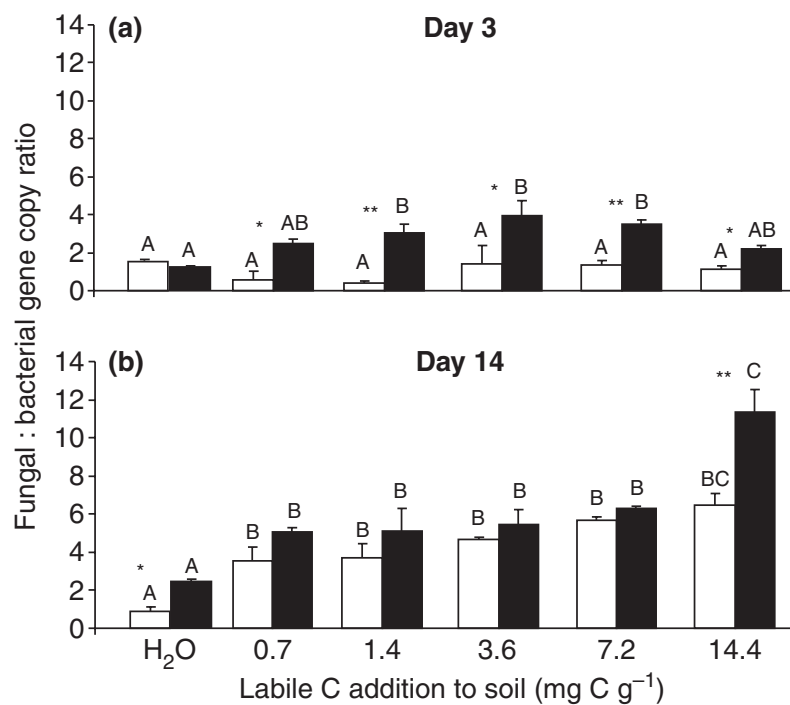

Fig. 2 Fungal : bacterial gene copy ratios in soils exposed to the different labile carbon (C) addition treatments. Open bars, samples that received labile $C$ additions only; closed bars, samples that received labile $C$ and plant residue at days 3 (a) and 14 (b) of the incubation. Different letters above the bars indicate significant differences among treatments $(P \leq 0.05)$ as induced by different labile $C$ inputs within a group (i.e. soil with added exudates, or soil with added exudates and plant residue). Asterisks indicate significant differences between groups (i.e. soil with added exudates, or soil with added exudates and plant residue) within each labile $C$ addition treatment, Significance: ${ }^{*}, P \leq 0.05 ;{ }^{*}, P \leq 0.01$. Values are means $\pm \mathrm{SE}(n=3)$.

numbers were enhanced at exudate additions of 0.7

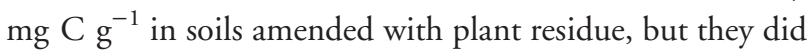
not consistently increase with higher concentrations of $\mathrm{C}$ $(P \leq 0.05$; Table 3).

Table 3 Soil fungal and bacterial gene copy number for the 16S : 18S subunit (qPCR) under five different labile carbon (C) additions

\begin{tabular}{|c|c|c|c|c|}
\hline \multirow[b]{2}{*}{ Treatments } & \multicolumn{2}{|c|}{ Bacterial gene copy numbers } & \multicolumn{2}{|c|}{ Fungal gene copy numbers } \\
\hline & Day 3 & Day 14 & Day 3 & Day 14 \\
\hline Water only & $(8.4 \pm 0.2) \times 10^{5} \mathrm{a}$ & $(7.9 \pm 0.3) \times 10^{5} a$ & $(1.3 \pm 0.3) \times 10^{6} \mathrm{~b}$ & $(7.1 \pm 1.7) \times 10^{5} \mathrm{a}$ \\
\hline $0.7 \mathrm{mg} \mathrm{C} \mathrm{g}^{-1}$ & $(8.3 \pm 0.4) \times 10^{5} a$ & $(9.4 \pm 0.9) \times 10^{5} \mathrm{a}$ & $(4.7 \pm 0.7) \times 10^{5} a$ & $(3.3 \pm 0.5) \times 10^{6} b$ \\
\hline $1.4 \mathrm{mg} \mathrm{C} \mathrm{g}^{-1}$ & $(9.5 \pm 0.5) \times 10^{5} a$ & $(1.2 \pm 0.01) \times 10^{6} a$ & $(3.7 \pm 0.9) \times 10^{5} a$ & $(4.6 \pm 1.7) \times 10^{6} \mathrm{~b}$ \\
\hline $3.6 \mathrm{mg} \mathrm{C} \mathrm{g}^{-1}$ & $(9.4 \pm 1.7) \times 10^{5} a$ & $(1.2 \pm 0.1) \times 10^{6} a$ & $(1.3 \pm 0.5) \times 10^{6} \mathrm{~b}$ & $(5.4 \pm 0.3) \times 10^{6} b$ \\
\hline $7.2 \mathrm{mg} \mathrm{C} \mathrm{g}^{-1}$ & $(9.9 \pm 1.0) \times 10^{5} \mathrm{a}$ & $(1.3 \pm 0.04) \times 10^{6} \mathrm{a}$ & $(1.4 \pm 0.1) \times 10^{6} b$ & $(7.4 \pm 0.7) \times 10^{6} b$ \\
\hline $14.4 \mathrm{mg} \mathrm{C} \mathrm{g} 1$ & $(1.6 \pm 0.1) \times 10^{6} b$ & $(1.6 \pm 0.3) \times 10^{6} b$ & $(1.7 \pm 0.3) \times 10^{6} b$ & $(1.0 \pm 0.1) \times 10^{7} c$ \\
\hline Soil + plant residue & $(1.8 \pm 0.1) \times 10^{6} b$ & $(1.2 \pm 0.1) \times 10^{6} \mathrm{a}$ & $(2.1 \pm 0.1) \times 10^{6} a$ & $(2.9 \pm 0.5) \times 10^{6} a$ \\
\hline $0.7 \mathrm{mg} \mathrm{C} \mathrm{g}^{-1}+$ plant residue & $(1.5 \pm 0.1) \times 10^{6} \mathrm{a}$ & $(1.5 \pm 0.1) \times 10^{6} b$ & $(3.6 \pm 0.1) \times 10^{6} \mathrm{a}$ & $(7.7 \pm 0.6) \times 10^{6} \mathrm{~b}$ \\
\hline $1.4 \mathrm{mg} \mathrm{C} \mathrm{g}^{-1}+$ plant residue & $(1.4 \pm 0.2) \times 10^{6} a$ & $(1.5 \pm 0.1) \times 10^{6} b$ & $(4.1 \pm 0.4) \times 10^{6} a$ & $(7.6 \pm 2.6) \times 10^{6} \mathrm{~b}$ \\
\hline $3.6 \mathrm{mg} \mathrm{C} \mathrm{g}^{-1}+$ plant residue & $(2.4 \pm 0.2) \times 10^{6} \mathrm{c}$ & $(1.6 \pm 0.3) \times 10^{6} a, b$ & $(9.3 \pm 1.2) \times 10^{6} b$ & $(8.7 \pm 1.2) \times 10^{6} b$ \\
\hline $7.2 \mathrm{mg} \mathrm{C} \mathrm{g} \mathrm{g}^{-1}+$ plant residue & $(2.5 \pm 0.2) \times 10^{6} \mathrm{c}$ & $(2.0 \pm 0.2) \times 10^{6} b, c$ & $(8.9 \pm 1.1) \times 10^{6} b$ & $(1.3 \pm 0.2) \times 10^{7} b, c$ \\
\hline $14.4 \mathrm{mg} \mathrm{C}^{-1}+$ plant residue & $(3.2 \pm 0.1) \times 10^{6} d$ & $(1.0 \pm 0.2) \times 10^{6} \mathrm{a}$ & $(6.9 \pm 0.5) \times 10^{6} b$ & $(1.2 \pm 0.3) \times 10^{7} b, c$ \\
\hline
\end{tabular}

qPCR, quantitative polymerase chain reaction.

From left to right, columns represent: bacterial gene copy numbers on day 3 of the incubation, bacterial gene copy numbers on day 14 of the incubation, fungal gene copy numbers on day 3 of the incubation, and fungal gene copy numbers on day 14 of the incubation.

Different letters indicate differences among treatments $(P \leq 0.05)$ among $C$-addition treatments within each table column. Values are mean $\pm \mathrm{SE}(n=3)$. 


\section{Discussion}

The addition of exudates to soil enhanced both overall $\mathrm{CO}_{2}$ respiration and bacterial and fungal gene copy numbers. However, the composition of respired $\mathrm{CO}_{2}$ (i.e. the abundance of soil plus exudate-derived $\mathrm{CO}_{2}$ relative to plant residue-derived $\mathrm{CO}_{2}$ ) was determined by the amount of labile $\mathrm{C}$ added to the soil. Additions of low amounts of substrate (i.e. $0.7 \mathrm{mg} \mathrm{C} \mathrm{g}^{-1}$ ) increased plant residue decomposition, without detectable increases in relative fungal or bacterial gene copy numbers. At intermediate additions (i.e. 1.4 and $3.6 \mathrm{mg} \mathrm{C} \mathrm{g}^{-1}$ ), decomposition of the plant residues remained similar to decomposition of residues when only water was added, although total microbial respiration and relative microbial gene copy numbers were enhanced. By contrast, the highest amount of labile C inputs to the soil (i.e. $>3.6 \mathrm{mg} \mathrm{C} \mathrm{g}^{-1}$ ) had the greatest stimulating effect on relative microbial gene copy numbers and total respiration rates, but it also significantly reduced plant residue decomposition.

Our results, that labile $\mathrm{C}$ inputs can increase, have no effect on, or decrease more recalcitrant $\mathrm{C}$ decomposition in soil, support previous findings (Kuzyakov, 2002; Blagodatskaya \& Kuzyakov, 2008). For example, several studies found only apparent priming effects when labile C was added to soil (Dalenberg \& Jager, 1981, 1989; Chapman \& Gray, 1986; De Nobili et al., 2001). By contrast, others have found either positive (Kuzyakov et al., 2007; Hamer \& Marschner 2005a,b), or negative priming effects when labile $\mathrm{C}$ was added to soil (Kuzyakov \& Bol, 2006; Blagodatskaya et al., 2007). In many cases this variability cannot be explained by the amount of labile C added to the soil system. For example, Hamer \& Marschner (2005b) observed large $(+63 \%)$ increases in native SOM decomposition following additions of labile $\mathrm{C}$ in similar concentrations to our 'low' additions, whereas others found no impact of labile $\mathrm{C}$ inputs on decomposition of more stable $\mathrm{C}$ following labile $\mathrm{C}$ additions at a 10-fold smaller rate (Blagodatskaya et al., 2007; Kuzyakov et al., 2007). However, none of the previous studies examined decomposition and concomitant microbial responses to a range of labile $\mathrm{C}$ inputs to soil. Our results suggest that the amount of labile soil $\mathrm{C}$ input can either increase or decrease decomposition of more recalcitrant soil C, by changing the relative abundance of bacteria and fungi originally present in the soil. Therefore, our results shed light on some of the variation found in previous studies and thus enable better predictions of when priming may occur in soils.

Clearly, soil microbial communities are important in SOM decomposition and they respond quickly to changes in labile soil $\mathrm{C}$ additions because they are often C-limited, (Bowen \& Rovira, 1991; Darrah, 1996). Thus, their response to $\mathrm{C}$ additions should regulate priming effects. In a literature synthesis, Blagodatskaya \& Kuzyakov (2008) proposed that the size of the soil microbial biomass $\mathrm{C}$ strongly regulates the impact of added substrate $\mathrm{C}$ on the direction of the priming effect. While we cannot explicitly test for this in our study because our qPCR-generated gene copy numbers do not reflect changes in the absolute abundance of microorganisms (Fierer et al., 2005; Rousk et al., 2010), the relative increase in microbial gene copy numbers within both bacterial and fungal groups with increasing $\mathrm{C}$ additions in our study lends support for this hypothesis. We observed a real positive priming effect when small amounts of exudate input stimulated microbial metabolic activity, leading to an increased need for $\mathrm{C}$ by the microbial community irrespective of its source (i.e. plant residues or native $\mathrm{SOM}$ ). Intermediate inputs stimulated relative microbial gene copy numbers to the extent that the active microbial community could be supported by both labile $\mathrm{C}$ and residue C. By contrast, when high inputs of labile $\mathrm{C}$ were sufficient to support the relative increase in microbial abundance, the microbial community preferentially consumed the most labile substrate leading to a real negative priming effect, a mechanism proposed previously (Cheng, 1996; Cheng \& Kuzyakov, 2005). Our results indicate that the threshold for a priming effect is determined by the interaction between substrate addition and the active microbial community.

Changes in microbial community structure, in addition to or instead of changes in relative abundances of bacteria and fungi, may also regulate priming effects. Fontaine et al. (2003) proposed that positive priming results from the succession of fast-growing, competitive microorganisms to more slow-growing microbial communities that specialize in the decomposition of more recalcitrant C. However, Hamer \& Marschner (2005b) point out that rapid increases in SOC mineralization after substrate additions might indicate that fast-growing microorganisms are driving positive priming effects. Similar to previous work, we measured a greater increase in fast-growing fungi relative to bacteria upon labile $\mathrm{C}$ additions, resulting in enhanced fungal : bacterial gene copy ratios (Griffiths et al., 1998; Broeckling et al., 2008; Chiginevaa et al., 2009). Chiginevaa et al. (2009) suggested that these fungi belong to a fast-growing fungal group that specializes in metabolizing relatively large amounts of labile C-rich substrates. The significant shift toward fungal decomposition on day 3 in our study appeared to result in an apparent or negative priming effect, whereas no detectable change in fungal : bacterial gene copy ratios on day 3 of our study yielded a positive priming effect. Given this, our data suggest that upon substrate addition, an increase in the activation of the innate soil microbial community, without large shifts in microbial functional groups, can lead to a real positive priming effect.

The response of microbial $\mathrm{C}$ respiration to exudate input in our study was rapid, and was followed by a steep decline. 
Such swift increases (1-3 d) and subsequent decreases in microbial $\mathrm{CO}_{2}$ respiration following a one-time addition of labile C to soil are common (Wu et al., 1993; Bremer \& Kuikman, 1997; Mondini et al., 2006; Jones \& Murphy, 2007; Hoyle et al., 2008). However, under field conditions, plants exude labile $\mathrm{C}$ into soil continuously, potentially reducing the need for a priming effect of more recalcitrant soil C. Nonetheless, continuous addition of $\mathrm{C}$ at a rate of $10 \mu \mathrm{g} \mathrm{C} \mathrm{g}^{-1}$ soil $\mathrm{d}^{-1}$ showed a similar increase in plant residue mineralization (Kuzyakov et al., 2007). This suggests that under more natural conditions, with a continuous input of labile $\mathrm{C}$ to soil, an overall greater $\mathrm{C}$ requirement by the microbial community promotes degradation (priming) of more stable soil C. Further, root exudation is not necessarily a continuous steady-state process, but can occur locally at the root tip in sudden large bursts (Jaeger et al., 1999; Farrar et al., 2003). These pulsed inputs are similar to our experimental design and can lead to intermittent periods of microbial growth and subsequent exhaustion of C substrates (Kuzyakov et al., 2007). Such events may be important in controlling priming effects in soils, as the enhanced microbial biomass may have to be supported in the longer term by decomposition of more recalcitrant soil C, or of plant residue additions (Kuzyakov et al., 2007).

Despite a general fast response in metabolic activity of the microbial community, we found a greater time lag in maximum $\mathrm{CO}_{2}$ respiration with increasing substrate additions. In fact, the maximum respiration rate occurred at day 1 for the lowest labile $\mathrm{C}$ addition and at days 2, 3, and 4 with increasing $\mathrm{C}$ additions. Such time lags have been observed previously (Schneckenberger et al., 2008) and are most likely associated with the inability of soil microbes to take up and utilize large amounts of labile C, microbial growth, and shifts in the microbial community (Blagodatskaya \& Kuzyakov, 2008). While our experiment is unable to tease apart which of these three mechanisms is responsible for the observed time lag in $\mathrm{C}$ degradation, it supports the results of previous studies (Anderson \& Domsch, 1978).

Plants can allocate $\mathrm{C}$ above and below ground and the amount of allocation can change in response to a variety of perturbations, such as changing atmospheric $\mathrm{CO}_{2}$ concentration (de Graaff et al., 2009; Iversen, 2010) and herbivory (Dyer \& Bokhari, 1976; Guitian \& Bardgett, 2000; Hamilton \& Frank, 2001). If these perturbations alter the amount of $\mathrm{C}$ being shunted below ground, the rate of $\mathrm{C}$ degradation in soils may change. Of course, other factors that we did not investigate might alter the response we observed. For example, root exudates collected in natural ecosystems are complex and contain a wide array of secondary chemicals that we did not include in our cocktail (Dakora \& Phillips, 2002; Dennis et al., 2010). Shifts in secondary metabolites, for example, might alter the response of the microbial community (Wu et al., 1993; Fontaine et al.,
2003; Hamer \& Marschner 2005a; Dennis et al., 2010). Similarly, different soil types and their associated microbial communities may respond to labile $\mathrm{C}$ substrate additions in different ways (Kuzyakov et al., 2000). Nonetheless, our data clearly show how small changes in below-ground C allocations may change associated decomposition processes and the communities responsible for those changes.

\section{Conclusions}

The quantity of exudate input to soil appears to strongly mediate decomposition rates of plant residue by controlling the direction of the priming effect. Each step-increase in labile $\mathrm{C}$ addition significantly enhanced microbial $\mathrm{CO}_{2}$ respiration. Exudate concentrations in excess of $3.6 \mathrm{mg} \mathrm{C} \mathrm{g}^{-1}$ appeared to promote competitive fungal and bacterial groups, leading to preferential substrate utilization and a negative priming effect. By contrast, exudate additions at concentrations of $0.7 \mathrm{mg} \mathrm{C} \mathrm{g}^{-1}$ soil d ${ }^{-1}$ did not significantly enhance bacterial or fungal gene copy numbers, but triggered metabolic activity of the microbial community resulting in a positive priming effect. Future work should investigate how different types of root-specific compounds alter SOM decomposition, what the role of microbial abundance vs community structure is in these processes, and how different types on perturbations may influence these patterns across ecosystems.

\section{Acknowledgements}

Joanne Childs, Scott Hawley, and Tyler Clement assisted with the laboratory work and analyses. Charles Garten Jr performed the residue quality and isotope analyses. Five reviewers provide invaluable feedback on this manuscript. This research was sponsored by the US Department of Energy, Office of Science, Biological and Environmental Research and conducted at Oak Ridge National Laboratory, which is managed by UT Battelle, LLC, for the US Department of Energy under Contract DE-AC05$00 \mathrm{OR} 22725$.

\section{References}

Anderson JPE, Domsch KH. 1978. A physiological method for the quantitative measurement of microbial biomass in soils. Soil Biology \& Biochemistry 10: 215-221.

Blagodatskaya E, Kuzyakov Y. 2008. Mechanisms of real and apparent priming effects and their dependence on soil microbial biomass and community structure: critical review. Biology and Fertility of Soils 45: $115-131$.

Blagodatskaya EV, Blagodatsky SA, Anderson T-H, Kuzyakov Y. 2007. Priming effects in Chernozem induced by glucose and $\mathrm{N}$ in relation to microbial growth strategies. Applied Soil Ecology 37: 95-105.

Borneman J, Hartin RJ. 2000. PCR primers that amplify fungal rRNA genes from environmental samples. Applications in Environmental Microbiology 66: 4356-4360. 
Bowen CB, Rovira AD. 1991. The rhizosphere: the hidden half of the hidden half. In: Waisel Y, Eshel A, Kafkafi U, eds. Plant roots: the hidden half. New York, NY, USA: Dekker, 641-669.

Bremer E, Kuikman P. 1997. Microbial utilization of ${ }^{14} \mathrm{C}$-glucose in soil is affected by the amount and timing of glucose additions. Soil Biology \& Biochemistry 26: 511-517.

Broeckling CD, Broz AK, Bergelson J, Manter DK, Vivanco JM. 2008. Root exudates regulate soil fungal community composition and diversity. Applied and Environmental Microbiology 74: 738-744.

Castro HF, Classen AT, Austin EE, Norby RJ, Schadt CW. 2010. Soil microbial community responses to multiple experimental climate change drivers. Applied and Environmental Microbiology 76: 9991007.

Chapman SJ, Gray TRG. 1986. Importance of cryptic growth, yield factors and maintenance energy in models of microbial growth in soil. Soil Biology \& Biochemistry 18: 1-4.

Cheng W. 1996. Measurement of rhizosphere respiration and organic matter decomposition using natural ${ }^{13} \mathrm{C}$. Plant and Soil 183: 263-268.

Cheng W, Kuzyakov Y. 2005. Root effects on soil organic matter decomposition. In: Zobel RW, Wright SF, eds. Roots and soil management: interactions between roots and the soil. Madison, WI, USA: Agronomy Monograph, 119-143.

Chiginevaa NI, Aleksandrovab AV, Tiunovc AV. 2009. The addition of labile carbon alters residue fungal communities and decreases residue decomposition rates. Applied Soil Ecology 42: 264-270.

Dakora FD, Phillips DA. 2002. Root exudates as mediators of mineral acquisition in low-nutrient environments. Plant and Soil 245: $35-47$.

Dalenberg JW, Jager G. 1981. Priming effect of small glucose additions to ${ }^{14} \mathrm{C}$-labelled soil. Soil Biology \& Biogeochemistry 3: 219-223.

Dalenberg JW, Jager G. 1989. Priming effect of some organic additions to C-14 labeled soil. Soil Biology \& Biochemistry 21: 443-448.

Darrah PR. 1996. Rhizodeposition under ambient and elevated $\mathrm{CO}_{2}$ levels. Plant and Soil 187: 265-275.

De Deyn GB, Cornelissen JHC, Bardgett RD. 2008. Plant functional traits and soil carbon sequestration in contrasting biomes. Ecology Letters 11: 516-531.

De Nobili M, Contin M, Mondini C, Brookes PC. 2001. Soil microbial biomass is triggered into activity by trace amounts of substrate. Soil Biology \& Biochemistry 33: 1163-1171.

Denef K, Six J, Merckx R, Paustian K. 2002. Short-term effects of biological and physical forces on aggregate formation in soils with different clay minerolagy. Plant and Soil 246: 185-200.

Dennis PG, Miller AJ, Hirsch PR. 2010. Are root exudates more important than other sources of rhizodeposits in structuring rhizosphere bacterial communities? Fems Microbial Ecology 72: 313-327.

Dormaar JF. 1990. Effect of active roots on the decomposition of soil organic materials. Biology and Fertility of Soils 10: 121-126.

Dyer MI, Bokhari UG. 1976. Plant-animal interactions: studies of the effects of grasshopper grazing on blue gramma grass. Ecology 57: 762-772.

Farrar J, Hawes M, Jones D, Lindow S. 2003. How roots control the flux of carbon to the rhizosphere. Ecology 84: 827-837.

Fierer N, Jackson JA, Vilgalys R, Jackson RB. 2005. Assessment of soil microbial community structure by use of taxon-specific quantitative PCR assays. Applications in Environmental Microbiology 71: 4117-4120.

Fontaine S, Barot S. 2005. Size and functional diversity of microbe populations control plant persistence and long-term soil carbon accumulation. Ecology Letters 8: 1075-1087.

Fontaine S, Mariotti A, Abbadie L. 2003. The priming effect of organic matter: a question of microbial competition? Soil Biology \& Biochemistry 35: 837-843.

de Graaff M-A, Six J, Harris D, Blum H, van Kessel C. 2004.

Decomposition of soil and plant carbon from pasture systems after nine years of exposure to elevated $\mathrm{CO}_{2}$. Global Change Biology 10: 1922 1935.

de Graaff M-A, Six J, van Kessel C. 2009. Rhizodeposition-induced decomposition increases $\mathrm{N}$ availability to wild and cultivated wheat genotypes under elevated $\mathrm{CO}_{2}$. Soil Biology \& Biochemistry 41: 10941103.

Griffiths BS, Ritz K, Ebblwhite N, Dobson G. 1998. Soil microbial community structure: effects of substrate loading rates. Soil Biology and Biochemistry 31: 145-153.

Guitian R, Bardgett RD. 2000. Plant and soil microbial responses to defoliation in temperate semi-natural grassland. Plant and Soil 220: 271-277.

Hamer U, Marschner B. 2002. Priming effects of sugars, amino acids, organic acids and catechol on the mineralization of lignin and peat. Journal of Plant Nutrition and Soil Science 165: 261-268.

Hamer U, Marschner B. 2005a. Priming effects in different soil types after addition of fructose, alanine, oxalic acid or catechol. Soil Biology \& Biochemistry 37: 445-454.

Hamer U, Marschner B. 2005b. Priming effects in soils after combined and repeated substrate additions. Geoderma 128: 38-51.

Hamer U, Marschner B, Brodowski S, Amelung W. 2004. Interactive priming of black carbon and glucose mineralisation. Organic Geochemistry 35: 823-830.

Hamilton WE III, Frank DA. 2001. Can plants stimulate microbes and their own nutrient supply? Evidence from a grazing tolerant grass. Ecology 82: 2397-2402.

Hoyle FC, Murphy DV, Brookes PC. 2008. Microbial response to the addition of glucose in low-fertility soils. Biology and Fertility of Soils 44: 571-579.

Hutsch BW, Augustin J, Merbach W. 2002. Plant rhizodeposition: an important source for carbon turnover in soils. Journal of Plant Nutrition and Soil Science 165: 397-407.

Iversen CM. 2010. Digging deeper: fine root responses to rising atmospheric $\mathrm{CO}_{2}$ concentration in forested ecosystems. New Phytologist 186: 346-357.

Jaeger CH III, Lindow SE, Miller W, Clark E, Firestone MK. 1999. Mapping of sugar and amino acid availability in soil around roots with bacterial sensors of sucrose and tryptophan. Applied and Environmental Microbiology 65: 2685-2690.

Jastrow JD, Amonette JE, Bailey VL. 2007. Mechanisms controlling soil carbon turnover and their potential application for enhancing carbon sequestration. Change 80: 5-23.

Jones DL. 1998. Organic acids in the rhizosphere. A critical review. Plant and Soil 205: 25-44.

Jones DL, Darrah PR. 1993. Re-sorption of organic compounds by roots of Zea mays L. and its consequences in the rhizosphere. II. Experimental and model evidence for simultaneous exudation and re-sorption of soluble C compounds. Plant and Soil 153: 47-59.

Jones DL, Murphy DV. 2007. Microbial response time to sugar and amino acid additions to soil. Soil Biology \& Biochemistry 39: 2178-2182.

Kraffczyk I, Trolldenier G, Beringer H. 1984. Soluble root exudates of maize: influence of potassium supply and rhizosphere microorganisms. Soil Biology \& Biochemistry 16: 315-322.

Kuzyakov Y. 2002. Review: factors affecting rhizosphere priming effects. Journal of Plant Nutrition and Soil Science 165: 382-396.

Kuzyakov Y, Bol R. 2006. Sources and mechanisms of priming effect induced in two grassland soils amended with slurry and sugar. Soil Biology \& Biochemistry 38: 747-758.

Kuzyakov Y, Friedel JK, Stahr K. 2000. Review of mechanisms and quantification of priming effects. Soil Biology \& Biochemistry 32: 14851498.

Kuzyakov Y, Hill PW, Jones DL. 2007. Root exudate components change residue decomposition in a simulated rhizosphere depending on temperature. Plant and Soil 290: 293-305. 
Lal R. 2004. Soil carbon sequestration to mitigate climate change. Geoderma 123: 1-22.

Lane DJ. 1991. 16S/23S rRNA sequencing. In: Stackebrandt E, Goodfellow M, eds. Nucleic acid techniques in bacterial systematics. Chichester, UK: J. Wiley \& Sons, 115-175.

Lynch JM, Whipps JM. 1990. Substrate flow in the rhizosphere. Plant and Soil 129: 1-10.

Meharg AA, Kilham K. 1995. A novel method of quantifying root exudation in the presence of soil microflora. Plant and Soil 113: 111116.

Merckx R, van Ginkel J, Sinnaeve J, Cremers A. 1986. Plant-induced changes in the rhizosphere of maize and wheat. Part 1 Production and turnover of root-derived materials. Plant and Soil 96: 85-93.

Mondini C, Cayuela ML, Sanchez-Monedero MA, Roig A, Brookes PC. 2006. Soil microbial biomass activation by trace amounts of readily available substrate. Biology and Fertility of Soils 42: 542-549.

Muyzer G, Dewaal EC, Uitterlinden AG. 1993. Profiling of complex microbial- populations by denaturing gradient gel-electrophoresis analysis of polymerase chain reaction-amplified genes-coding for 16 s ribosomalRNA. Applications in Environmental Microbiology 59: 695-700.
Phillips R. 2007. Toward a rhizocentric view of plant-microbial feedbacks under elevated atmospheric $\mathrm{CO}_{2}$. New Phytologist 173: 664-667.

Rousk J, Baath E, Bookes PC, Lauber CL, Lozupone C, Caporaso JG, Knight R, Fierer N. 2010. Soil bacterial and fungal communities across a pH gradient in an arable soil. The ISME Journal 10: 1-12.

Schneckenberger K, Demin D, Stahr K, Kuzyakov Y. 2008. Microbial utilization and mineralization of $\left[{ }^{14} \mathrm{C}\right]$ glucose added in six orders of concentration to soil. Soil Biology \& Biochemistry 40: 1981-1988.

Strickland MS, Rousk J. 2010. Considering fungal:bacterial dominance in soil - methods, controls, and ecosystem implications. Soil Biology \& Biochemistry doi: 10.1016/j.soilbio.2010.05.007.

Trofymow JA, Coleman DC, Cambardella C. 1987. Rates of rhizodeposition and ammonium depletion in the rhizosphere of axenic oat roots. Plant and Soil 97: 333-344.

Wardle DA, Bonner KI, Barker GM. 2002. Linkages between plant litter decomposition, litter quality, and vegetation responses to herbivores. Functional Ecology 16: 585-595.

Wu J, Brookes PC, Jenkinson DS. 1993. Formation and destruction of microbial biomass during the decomposition of glucose and ryegrass in soil. Soil Biology \& Biochemistry 25: 1435-1441.

\section{About New Phytologist}

- New Phytologist is owned by a non-profit-making charitable trust dedicated to the promotion of plant science, facilitating projects from symposia to open access for our Tansley reviews. Complete information is available at www.newphytologist.org.

- Regular papers, Letters, Research reviews, Rapid reports and both Modelling/Theory and Methods papers are encouraged. We are committed to rapid processing, from online submission through to publication 'as-ready' via Early View - our average submission to decision time is just 29 days. Online-only colour is free, and essential print colour costs will be met if necessary. We also provide 25 offprints as well as a PDF for each article.

- For online summaries and ToC alerts, go to the website and click on 'Journal online'. You can take out a personal subscription to the journal for a fraction of the institutional price. Rates start at $£ 149$ in Europe $\$ 276$ in the USA \& Canada for the online edition (click on 'Subscribe' at the website).

- If you have any questions, do get in touch with Central Office (newphytol@lancaster.ac.uk; tel +44 1524 594691) or, for a local contact in North America, the US Office (newphytol@ornl.gov; tel +1 865576 5261). 